\title{
Analisis Dampak Perhitungan Aset Tetap Berdasarkan Jenis Kelompok, Masa Manfaat, Tarif Penyusutan Berdasarkan Undang - Undang Perpajakan Pasal 11 Pph No. 36 Tahun 2008 Terhadap Laba Rugi PT Wahana Kreasi Nusantara Tahun 2013 - 2018
}

\author{
Diana Gustinya \\ Fakultas Ekonomi Universitas Krisnadwipayana \\ Jalan Unkris Jatiwaringin Jakarta Timur \\ Email: dianagustinya@gmail.com
}

\begin{abstract}
To find out the calculation of fixed assets based on the type of group, useful life, depreciation rates of the Taxation Act (article 11 of the Income Tax Law No. 36 of 2008) at PT Wahana Kreasi Nusantara. And the impact of applying the difference in the calculation of depreciation of fixed assets on the income statement of PT Wahana Kreasi Nusantara from 2013 to 2018. This study uses a descriptive qualitative method with secondary data used in this study is the data of fixed assets and income statements of PT Wahana Kreasi Nusantara from 2013 to 2018. PT Wahana Kreasi Nusantara uses the straight-line method in calculating all its fixed assets, but in determining the type of group, the useful life and depreciation rates determined by the company are not in accordance with the Taxation Law Regulation (article 11 of Income Tax Law No. 36 years 2008). So that the incompatibility of types of groups, the useful life and depreciation rates between companies with the Taxation Law Regulation (article 11 of the Income Tax Law No. 36 of 2008) results in the difference in depreciation costs incurred by the company each period that affects the income statement.
\end{abstract}

Keyword: Aset tetap, Penyusutan, PPh, Laba Rugi,

\section{PENDAHULUAN}

Aset tetap pada suatu perusahaan merupakan sarana penunjang kegiatan operasional yang digunakan untuk membantu perusahaan dalam menghasilkan laba atau keuntungan perusahaan Penggunaan aset tetap tersebut mewajibkan perusahaan dalam mengeluarkan biaya untuk memperoleh maupun perawatan aset. Aset tetap yang dimiliki perusahaan harus bisa memberikan masa manfaat bagi perusahaan selama bertahun - tahun. Masa manfaat yang diberikan oleh perusahaan terhadap aset tetap dari tahun ketahun mengalami menurun pemakaiannya, dan menyebabkan terjadinya penyusutan.
Ada perbedaan ketentuan yang mengatur perhitungan penyusutan aset tetap yaitu ketentuan menurut pernyataan standar akuntansi keuangan (PSAK) No.16 dengan ketentuan Peraturan Perundang - undangan Perpajakan No.36 Tahun 2008 Tentang pajak penghasilan, perbedaan tersebut antara lain metode penyusutan, tarif penyusutan, dan masa manfaat atau umur ekonomis suatu aset tetap.

PT Wahana Kreasi Nusantara merupakan perusahaan yang bergerak dalam jasa kereta gantung (Gondola). Dalam menjalankan kegiatan aktivitas perusahaan tidak terlepas dari aset tetap perusahan, aset tetap yang dimiliki oleh PT Wahana Kreasi Nusantara berupa peralatan kantor, 
perlengkapan kantor, dan kendaraan operasional. Dalam melakukan perhitungan penyusutan aset tetap yang dimilikinya, PT Wahana Kreasi Nusantara melakukan perhitungan biaya penyusutan pada aset tetap yang dimiliki setiap periodenya sesuai dengan pernyataan standar akuntansi keuangan (PSAK 16) dengan metode garis lurus (straight line), dikarenakan perusahaan menganggap metode garis lurus (straight line) dinilai lebih praktis dan lebih sederhana dibandingkan dengan metode penyusutan yang lain.

Namun ketentuan perhitungan biaya penyusutan aset tetap menggunakan metode garis lurus berdasarkan PSAK No 16 yang dimiliki oleh PT Wahana Kreasi Nusantara seperti penentuan kelompok, masa manfaat dan tarif penyusutan pada setiap kelompok aset tetap berwujud tersebut belum sesuai dengan Peraturan Undang - Undang Perpajakan (pasal 11 Undang - Undang PPh No.36 tahun 2008 ).

Perbedaan perhitungan biaya penyusutan berdasarkan pernyataan standar akuntansi keuangan (PSAK) No.16 dan Pasal 11 Undang - Undang No.36 Tahun 2008 di PT Wahana Kreasi Nusantara mengakibatkan selisih biaya penyusutan aset tetap sebesar $\mathrm{Rp}$ 15.736.635 dan ini berdampak terhadap laporan keuangan laba rugi PT Wahana Kreasi Nusantara

Berdasarkan latar belakang yang telah diuraikan sebelumnya, maka penulis merumuskan masalah sebagai berikut:

1. Bagaimana perhitungan penyusutan aset tetap berdasarkan jenis kelompok, masa manfaat, tarif penyusutan pada PT Wahana Kreasi Nusantara?

2. Bagaimana perhitungan aset tetap berdasarkan berdasarkan jenis kelompok, masa manfaat, tarif penyusutan Peraturan Undang - Undang Perpajakan (pasal 11
Undang - Undang PPh No.36 tahun 2008 ) pada PT Wahana Kreasi Nusantara?

3. Bagaimana dampak penerapan perbedaan perhitungan penyusutan aset tetap berdasarkan jenis kelompok, masa manfaat, tarif penyusutan yang dilakukan berdasarkan pernyataan standar akuntansi keuangan (PSAK) No.16 dan Pasal 11 Undang - Undang No.36 Tahun 2008 terhadap laporan laba rugi PT Wahana Kreasi Nusantara tahun 2013 sampai dengan tahun 2018?

\section{TINJAUAN PUSTAKA}

\section{Aset Tetap}

Aset Tetap adalah aset berwujud yang dimiliki untuk digunakan dalam produksi atau penyediaan barang atau jasa, untuk disewakan kepada pihak lain, atau untuk tujuan administrasif, dan diharapkan untuk digunakan selama lebih dari satu periode. (Kartikahadi, 2016:76).

Menurut Hery (2014:39), asset tetap dikelompokan antara lain : Aset tetap berwujud (tangible assets), Aset tidak berwujud (intangible assets).

Waluyo (2016:108) mendefinisikan aset tetap merupakan bagian dari neraca yang dilaporkan oleh manajemen dalam setiap periode atau setiap tahun. Berdasarkan PSAP BA No. 7 Paragraf 7-14 PP No. 71 Tahun 2010 (Waluyo, 2016:108), aset tetap diklasifikasikan berdasarkan kesamaan dalam sifat atau fungsinya dalam aktivitas operasi perusahaan.

Aset tetap dapat diperoleh dengan berbagai macam cara, diantaranya yang paling sering terjadi biasanya dengan cara pembelian tunai, pembelian secara mengangsur atau pertukaran. Menurut 
ISSN : 2406-7415

e-ISSN : 2655-9919

JURNAL AKUNTANSI DAN BISNIS KRISNADWIPAYANA

Vol. 7 No. 1 (Januari - April) 2020

\section{DOI: $\underline{\text { http://dx.doi.org/10.35137/jabk.v7i1.376 }}$}

Waluyo (2016:111) adalah perolehan aset tetap secara gabungan, perolehan aset tetap secara angsuran, pembelian tunai, perolehan aset tetap secara pertukaran, perolehan aset tetap dengan cara membangun sendiri, perolehan secara hibah, bantuan, dan sumbangan.

Perusahaan mengakui suatu aset tetap apabila aset tetap tersebut telah diterima atau diserahkan hak kepemilikannya, dan atau pada saat penguasaannya berpindah. Oleh karena itu apabila belum ada bukti suatu aset dimiliki atau dikuasai oleh suatu perusahaan maka aset tetap tersebut belum dapat dicantumkan dineraca.

Biaya perolehan adalah jumlah kas atau setara kas yang dibayarkan atau nilai wajar dari imbalan lain yang diserahkan untuk memperoleh suatu aset pada saat perolehan atau konstruksi atau, jika dapat diterapkan, jumlah yang diatribusikan pada saat ketika pertama kali diakui sesuai dengan persyaratan tertentu dalam PSAK lain. Suatu aset tetap yang memenuhi kualifikasi diakui sebagai aset pada awal harus diukur sebagai biaya perolehan.

Dalam PSAK No.16 aset yang memenuhi kualifikasi untuk diakui sebagai aset pada awalnya harus diukur sebagai biaya perolehan. Pengertian biaya perolehan aset tetap adalah setara dengan nilai tunainya dan diakui pada saat terjadinya. Jika pembayaran ditangguhkan melampaui jangka waktu kredit normal, maka perbedaan antara harga tunai dan total pembayaran diakui sebagai beban bunga selama periode. Tetapi dikecualikan bila dikapitalisasi sesuai dengan perlakuan alternatif PSAK 26.

Menurut Nelson Lam (2014:374) model kebijakan akuntansi untuk seluruh aset tetap adalah model biaya dan model Revaluasi

\section{Penyusutan}

$\begin{array}{ccr}\text { Menurut } & \text { Samryn } & (2015: 164) \\ \text { mendefinisakan } & \text { penyusutan } & \text { adalah }\end{array}$
Penyusutan merupakan istilah yang dapat ditemukan sehari - hari sehubungan dengan penurunan nilai, manfaat, atau volume dari suatu aset atau kekayaan yang dimiliki.

James, dkk (2013:8) dalam bukunya berjudul pengantar akuntansi - adaptasi indonesia menyatakan bahwa penyusutan atau depresiasi adalah pemindahan biaya ke beban secara berkala. Sedangkan menurut Hery (2014:22), penyusutan adalah alokasi secara periodik dan sistematis dari harga perolehan asset selama periode - periode berbeda yang memperoleh manfaat dari penggunaan asset bersangkutan.

Penyusutan merupakan proses alokasi biaya perolehan menjadi sedemikian sehingga jumlah yang disusutkan dari suatu aset tetap dapat dialokasikan secara sistematis selama umur manfaatnya (Kartika Adi, 2012:344). Menurut Nordiawan (2007:4) salah satu dasar yang mendasari penyusutan adalah perbandingan biaya dan pendapatan (matching cost against revenue).

Suandy (2011:36) dan Hery (2014:142) memiliki pemikiran yang sama mengenai definisi beberapa metode yang berbeda mengenai perhitungan besarnya beban penyusutan yaitu

a. Berdasarkan kriteria waktu antara lain metode garis lurus (straight line method) dan metode pembebanan yang menurun (dipercepat).

b. Berdasarkan penggunaan yaiut metode jam jasa (service hours method) dan metode jumlah unit produksi (productive output method). 


\section{Penyusutan Asset Tetap Berdasarkan Peraturan Perpajakan}

Berdasarkan Undang - Undang Perpajakan menurut ketentuan perpajakan (pasal 11 Undang - Undang PPh No.36 tahun 2008 )

a. Metode garis lurus (straight line method), atau metode saldo menurun (declining balance method ) untuk aset tetap berwujud bukan bangunan.

b. Metode garis lurus untuk aset tetap berwujud berupa bangunan.

\section{Penyajian dan Pengungkapan Asset Tetap}

Pengungkapan informative dalam laporan keuangan harus dipandang memadai, kecuali dinyatakan lain dalam laporan auditor (Harahap, 2011:4). Jadi diharapkan agar laporan keuangan dapat disajikan secara penuh.

Penyusutan asset tetap menurut Kartikahadi (2012) mensyaratkan pengungkapan informasi untuk setiap kelompok asset sesuai PSAK dan PSAP yang dapat disusutkan sebagai berikut :

a. Dasar pengukuran yang digunakan dalam menentukan jumlah tercatat bruto

b. Metode penyusutan, umur manfaat dan tarif penyusutan yang digunakan

c. Jumlah tercatat bruto dan akumulasi penyusutan ( dijumlahkan dengan akumulasi rugi penurunan nilai ) pada awal dan akhir periode, dan rekonsiliasi jumlah tercatat pada awal dan akhir periode.

d. Penurunan nilai asset

e. Nilai pertanggungan asuransi atas asset tetap, jika asuransi dilakukan dan pendapat manajemen apakah nilai tersebut untuk itu.

\section{Penghentian dan Pelepasan Asset tetap}

Hery (2014:125) menjelaskan asset tetap yang tidak lagi memiliki umur manfaat yang lebih lama dapat dibuang, dijual atau ditukar dengan asset tetap lainnya.Dalam kasus pelepasan asset, nilai buku asset harus dihapus. Penghapusan nilai buku dilakukan dengan cara mendebet akun akumulasi penyusutan sebesar saldonya pada tanggal pelepasan asset dan mengkredit akun asset bersangkutan sebesar harga perolehannya (biaya historis).

\section{Laporan Keuangan}

Setelah transaksi dicatat dan diikhtisarkan, maka disiapkan laporan bagi pemakai. Laporan akuntansi yang menghasilkan informasi demikian disebut laporan keuangan. Laporan keuangan yang utama bagi perusahaan perseorangan adalah laporan laba rugi, laporan ekuitas pemilik, neraca, dan laporan arus kas. Urut-urutan penyusutan dan sifat data yang terdapat dalam laporan-laporan tersebut adalah sebagai berikut:

1. Laporan laba rugi - ikhtisar pendapatan dan beban selama periode waktu tertentu, misalnya sebulan atau setahun.

2. Laporan ekuitas pemilik - ikhtisar perubahan ekuitas pemilik yang terjadi selama periode waktu tertentu, misalnya sebulan atau setahun.

3. Neraca - daftar aset, kewajiban, dan ekuitas pemilik pada pada tanggal tertentu, biasanya pada akhir bulan atau akhir tahun.

4. Laporan arus kas - ikhtisar penerimaan kas dan pembayaran kas selama periode waktu tertentu, misalnya sebulan atausetahun.

\section{METODOLOGI PENELITIAN}


ISSN : 2406-7415

e-ISSN : 2655-9919

JURNAL AKUNTANSI DAN BISNIS KRISNADWIPAYANA

Vol. 7 No. 1 (Januari - April) 2020

\section{DOI: http://dx.doi.org/10.35137/jabk.v7i1.376}

Jenis penelitian yang digunakan dalam penelitian ini adalah deskriptif kualitatif, penelitian ini bertujuan untuk mengungkap kejadian atau fakta keadaan yang terjadi pada saat penelitian berjalan. Dengan memberikan analisis sesuai dengan apa yang terjadi pada perusahaan, kemudian memberikan kesimpulan tentang pengaruh perbedaan antara fakta yang ada dengan ketentuan - ketentuan yang berlaku. Data yang digunakan pada penelitian ini adalah data sekunder. Data sekunder merupakan data yang telah disajikan oleh perusahaan seperti data aset tetap, data perhitungan asset tetap, dan laporan laba rugi PT Wahana Kreasi Nusantara dan Peraturan Undang Undang Perpajakan (pasal 11 Undang Undang PPh No.36 tahun 2008 ). Yang digunakan sebagai acuan informasi penulis dalam melakukan penelitian.

Dalam penelitian ini, penulis melakukan analisis data dengan cara menganalisis perhitungan biaya penyusutan aset tetap PT Wahana Kreasi Nusantara. Mengamati kelompok aset tetap yang dimilikinya, dengan cara membandingkan jenis - jenis aset tetap, masa manfaat aset tetap dan tarif penyusutan aset tetap yang telah ditentukan oleh pernyataan standar akuntansi keuangan (PSAK) No.16 pada PT Wahana Kreasi Nusantara dengan ketentuan yang telah dibuat oleh Undang - Undang Perpajakan (pasal 11 Undang - Undang PPh No.36 tahun 2008). Agar dapat digunakan untuk menganalisis dampak perbedaan perhitungan aset tetap berdasarkan PT Wahana Kreasi Nusantara dengan Undang Undang Perpajakan (pasal 11 Undang Undang PPh No.36 tahun 2008) pada laporan laba rugi perusahaan.

\section{ANALISIS DAN PEMBAHASAN}

\section{Hasil Penelitian}

\section{Perhitungan Biaya Penyusutan Aset Tetap Berdasarkan Pernyataan Standar Akuntansi Keuangan (PSAK) No.16 Dengan Jenis Kelompok, Masa Manfaat, Tarif Penyusutan}

Penyusutan aset tetap yang dilakukan oleh PT Wahana Kreasi Nusantara berdasarkan pernyataan standar akuntansi keuangan (PSAK) No.16 menggunakan metode penyusutan garis lurus, dimana tipe aset tetap yang disusutkan dalam perusahaan adalah berupa kendaraan, perlengkapan, mesin dan peralatan kantor.

Pengelompokan aset tetap pada PT Wahana Kreasi Nusantara adalah sebagai berikut :

\section{Perlengkapan Kantor}

Perlengkapan kantor pada PT Wahana Kreasi Nusantara adalah berupa kursi, brangkas, printer, TV, AC, kipas angin, lemari kayu, lemari logam atau besi untuk arsip, lukisan, karpet, komputer, laptop, HT, dan scanner. PT Wahana Kreasi Nusantara memberikan masa manfaat untuk aset tetap tersebut sebesar 4 (empat) tahun dengan tarif penyusutan $25,00 \%$ dan nilai sisa aset tetap adalah 0 (nol). Berikut ini adalah salah satu contoh perhitungan aset tetap tipe aset berupa perlengkapan kantor :

Tipe Aset : Perlengkapan Kantor

Metode Penyusutan: Metode Garis Lurus

$\begin{array}{ll}\text { Jenis Aset } & \text { : Meja Kantor } \\ \text { Harga Perolehan } & : \text { Rp 33.997.000 } \\ \text { Masa Manfaat } & : 4 \text { (empat) Tahun } \\ \text { Tarif Penyusutan } & : 25,00 \% \\ \text { Perhitungan Biaya Penyusutan } & \begin{array}{c}\text { Biaya Penyusutan }= \\ \text { Harga Perolehan x Tarif } \\ \end{array} \\ & \text { Penyusutan }\end{array}$




$$
\begin{aligned}
& =\underset{25,00 \%}{\operatorname{Rp} 33.997 .000 \quad x} \\
& =\operatorname{Rp~8.499.250~}
\end{aligned}
$$

Sehingga biaya penyusutan aset tetap berupa jenis meja kantor tersebut mengalami penyusutan dari tahun pertama sampai tahun berakhirnya manfaat adalah sebesar $\mathrm{Rp}$ 8.499.250.

\section{Kendaraan}

Kendaraan pada PT Wahana Kreasi Nusantara terdiri dari dua jenis yaitu kendaraan roda dua (motor operasional) dengan masa manfaat untuk aset tetap tersebut sebesar 4 (empat) tahun dengan tariff penyusutan $25,00 \%$ dan nilai sisa aset tetap adalah 0 (nol), sedangkan kendaraan berroda empat (mobil operasional) dengan masa manfaat untuk aset tetap tersebut sebesar 8 (delapan) tahun dengan tariff penyusutan $12,50 \%$ dan nilai sisa aset tetap adalah 0 (nol). Berikut ini adalah salah satu contoh perhitungan aset tetap tipe aset berupa kendaraan :

a. Kendaraan Roda Dua (Motor)

Tipe Aset : Kendaraan

Metode Penyusutan : Metode Garis Lurus

Jenis Aset: Motor VIAR utk

Maintenance

Harga Perolehan : Rp 20.300.000

Masa Manfaat : 4 (empat) Tahun

Tarif Penyusutan : 25,00\%

Perhitungan Biaya Penyusutan

Biaya Penyusutan $=$ Harga Perolehan $\mathrm{x}$ Tarif Penyusutan

$=\operatorname{Rp} 20.300 .000 \times 25.00 \%$

$=\operatorname{Rp} 5.075 .000$

Sehingga biaya penyusutan aset tetap berupa jenis Motor VIAR utk Maintenance tersebut mengalami penyusutan dari tahun pertama sampai tahun berakhirnya manfaat adalah sebesar Rp 5.075.000.

b. Kendaraan Roda Empat (Mobil)

Tipe Aset : Kendaraan

Metode Penyusutan : Metode Garis Lurus

Jenis Aset : Mobil Luxio 1,5X A/T Warna Hitam

Harga Perolehan : Rp 214.562.000

Masa Manfaat : 8 (delapan) Tahun

Tarif Penyusutan : $12.50 \%$

Perhitungan Biaya Penyusutan

Biaya Penyusutan $=$ Harga Perolehan $\mathrm{x}$ Tarif Penyusutan

$=\operatorname{Rp} 214.562 .000 \times 12.50 \%$

$=\operatorname{Rp} 26.820 .250$

Sehingga biaya penyusutan aset tetap berupa jenis Mobil Luxio 1,5X A/T Warna Hitam tersebut mengalami penyusutan dari tahun pertama sampai tahun berakhirnya manfaat adalah sebesar Rp 26.820.250.

3. Mesin dan Peralatan Kantor

Yang termasuk dalam mesin dan peralatan kantor pada PT Wahana Kreasi Nusantara adalah Epson, mesin fax, cctv, mesin hitung uang, instalasi jaringan, alat pemadam kebakaran, telepon, mesin solar water healer, dispenser advance (alat penyaring air untuk minum). PT Wahana Kreasi Nusantara memberikan masa manfaat untuk aset tetap tersebut sebesar 4 (empat) tahun dengan tariff penyusutan $25,00 \%$ dan nilai sisa aset tetap adalah 0 (nol).

Tipe Aset : Mesin dan Peralatan Kantor Metode Penyusutan : Metode Garis Lurus

Jenis Aset : Solar Water Heater

Harga Perolehan : Rp 39.000.000 


$$
\begin{aligned}
& \text { Masa Manfaat : } 4 \text { (empat) Tahun } \\
& \text { Tarif Penyusutan : 25,00\% } \\
& \text { Perhitungan Biaya Penyusutan } \\
& \text { Biaya Penyusutan = Harga Perolehan x } \\
& \text { Tarif Penyusutan } \\
& =\operatorname{Rp} 39.000 .000 \times 25,00 \% \\
& =\operatorname{Rp} 9.750 .000
\end{aligned}
$$

Sehingga biaya penyusutan aset tetap berupa jenis meja kantor tersebut mengalami penyusutan dari tahun pertama sampai tahun berakhirnya manfaat adalah sebesar $\mathrm{Rp}$ 9.750.000.

Setelah melakukan perhitungan penyusutan pada salah aset tetap yang dimiliki oleh PT Wahana Kreasi Nusantara berdasarkan pernyataan standar akuntansi keuangan (PSAK) No.16, hasil penelitian selanjutnya adalah melakukan perhitungan penyusutan aset tetap pada seluruh aset tetap yang dimiliki perusahaan berdasarkan pernyataan standar akuntansi keuangan (PSAK) No.16, yang dilampiran 1 (satu) jumlah seluruh aset yang disusutkan oleh PT Wahana Kreasi Nusantara berdasarkan pernyataan standar akuntansi keuangan (PSAK) No.16 adalah sebesar Rp 1.191.403.350 dengan biaya penyusutan sebesar Rp 249.270.588.

2. Perhitungan Biaya Penyusutan Aset Tetap Berdasarkan Peraturan Undang - Undang Perpajakan (pasal 11 Undang - Undang PPh No.36 tahun 2008) Dengan Jenis Kelompok, Masa Manfaat, Tarif Penyusutan
Setelah melakukan perhitungan biaya penyusutan aset tetap menggunakan metode garis lurus berdasarkan kelompok aset tetap, masa manfaat aset tetap, dan tarif penyusutan aset tetap berdasarkan PT Wahana Kreasi Nusantara. Maka analisis penelitian selanjutnya adalah menganalisis perhitungan biaya penyusutan aset tetap menggunakan metode garis lurus berdasarkan kelompok aset tetap, masa manfaat aset tetap, dan tarif penyusutan aset tetap berdasarkan Peraturan Undang Undang Perpajakan (pasal 11 Undang Undang PPh No.36 tahun 2008 ) pada aset tetap yang dimiliki oleh PT Wahana Kreasi Nusantara.

\section{PEMBAHASAN}

Dari hasil penelitian diatas terlihat bahwa biaya penyusutan PT Wahana Kreasi Nusantara, sudah menggunakan metode perhitungan biaya penyusutan sesuai dengan Peraturan Undang - Undang Perpajakan (pasal 11 Undang - Undang PPh No.36 tahun 2008 ) yaitu metode garis lurus dengan nilai sisa aset tetap 0 (nol). Namun kelompok aset tetap, masa manfaat aset tetap, dan tarif penyusutan aset tetap belum sesuai dengan Peraturan Undang - Undang Perpajakan (pasal 11 Undang - Undang PPh No.36 tahun 2008 ). Seharusnya aset tetap berupa lemari arsip yang terbuat dari logam, AC, HT, kipas angin, mesin solar water heater, mesin penyaring air minum, dan instalasi jaringan termasuk dalam jenis jenis harta berwujud yang yermasuk dalam kelompok 2 dengan masa manfaat selama 8 (delapan) tahun dan tarif penyusutan pertahunnya sebesar $12,50 \%$.

Tabel 1. Perbandingan Perhitungan Biaya Penyusutan Aset Tetap Menggunakan 
Metode Garis Lurus Berdasarkan PSAK No.16 dengan Undang - Undang Perpajakan (pasal 11 Undang - Undang PPh No.36 tahun 2008 )Pada PT Wahana Kreasi Nusantara

\begin{tabular}{|c|c|c|c|c|}
\hline KETERANGAN & \multicolumn{2}{|c|}{ HARGA PEROLEHAN } & \multicolumn{2}{|c|}{ BIAYA PENYUSUTAN } \\
\hline $\begin{array}{l}\text { PT Wahana Kreasi } \\
\text { Nusantara }\end{array}$ & $\mathbf{R p}$ & 1.191 .403 .350 & Rp & 249.270.588 \\
\hline $\begin{array}{l}\text { Peraturan Undang- } \\
\text { Undang Perpajakan } \\
\text { (pasal 11 Undang - } \\
\text { Undang PPh No.36 } \\
\text { tahun 2008) }\end{array}$ & $\mathbf{R p}$ & 1.179 .653 .350 & $\mathbf{R p}$ & 177.892.974 \\
\hline & $\mathbf{R p}$ & 11.750 .000 & $\mathbf{R p}$ & 71.377.614 \\
\hline
\end{tabular}

Berdasarkan pernyataan standar akuntansi keuangan (PSAK) No.16 pada PT Wahana Kreasi Nusantara harga perolehan aset tetap yang disusutkan adalah sebesar Rp 1.191.403.350 sedangkan berdasarkan Peraturan Undang - Undang Perpajakan (pasal 11 Undang - Undang PPh No.36 tahun 2008) harga perolehan seluruh aset tetap yang disusutkan adalah sebesar $\mathrm{Rp}$ 1.179.653.350 selisih harga perolehan yang disusutkan berdaskan pernyataan standar akuntansi keuangan (PSAK) No.16 dengan Peraturan Undang - Undang Perpajakan (pasal 11 Undang - Undang PPh No.36 tahun 2008) pada PT Wahana Kreasi Nusantara sebesar Rp 11.750.000. Selisih tersebut disebabkan oleh jenis aset lukisan pada PT Wahana Kreasi Nusantara dilakukan penyusutan sedangkan lukiasan termasuk dalam jenis aset tidak berwujud, yang ditentukan dalam pasal 12 ayat (1) Undang-Undang Nomor 19 Tahun 2002 tentang Hak Cipta.

Dengan perbedaan harga perolehan antara PT Wahana Kreasi Nusantara dengan Peraturan Undang - Undang Perpajakan (pasal 11 Undang - Undang PPh No.36 tahun 2008) menghasilkan biaya penyusutan yang berbeda. Dengan harga perolehan yang ditetapkan oleh PT Wahana Kreasi Nusantara Rp 1.191.403.350 biaya penyusutan Rp 249.270.588, sedangkan berdasarkan Peraturan Undang - Undang Perpajakan (pasal 11 Undang - Undang PPh No.36 tahun 2008) harga perolehan seluruh aset tetap yang disusutkan adalah sebesar Rp 1.179.653.350 dengan biaya penyusutan $\mathrm{Rp}$ 177.892.974. Selisih biaya penyusutan berdasarkan pernyataan standar akuntansi keuangan (PSAK) No.16 dengan Peraturan Undang - Undang Perpajakan (pasal 11 Undang - Undang PPh No.36 tahun 2008) pada PT Wahana Kreasi Nusantara sebesar Rp 71.377.614 yang disebabkan karena perbedaan kelompok aset tetap, masa manfaat aset tetap dan tarif penyusutan aset tetap pertahunnya.

Setelah mengetahui perbedaan biaya penyusutan antara pernyataan standar akuntansi keuangan (PSAK) No.16 dengan Peraturan Undang - Undang Perpajakan (pasal 11 Undang - Undang PPh No.36 tahun 2008 ) pada PT Wahana Kreasi Nusantara, maka dalam pembahasan ini akan menganalisis pengaruh biaya penyusutan berdasarkan pernyataan standar akuntansi keuangan (PSAK) No.16 pada PT Wahana Kreasi Nusantara dengan Peraturan Undang - Undang Perpajakan (pasal 11 Undang - Undang PPh No.36 tahun 2008 ) pada laporan laba rugi perusahaan selama tahun 2013 sampai dengan tahun 2018. Biaya penyusutan yang dikeluarkan oleh PT Wahana Kreasi Nusantara setiap periodenya tidak sama, karena biaya penyusutan yang dikeluarkan tiap tahun berdasarkan harga perolehan aset tetap. 
Tabel 2. Perbandingan Perhitungan Biaya Penyusutan Aset Tetap Menggunakan Metode Garis Lurus Berdasarkan PSAK No.16 dengan pasal 11 Undang - Undang PPh No.36 tahun 2008 Pada Laporan Laba Rugi PT Wahana Kreasi Nusantara Tahun 2013 sampai Tahun 2018

\begin{tabular}{|c|c|c|c|c|}
\hline $\begin{array}{c}\text { Tahun } \\
\text { Penyusutan }\end{array}$ & Keterangan & $\begin{array}{c}\text { PT Wahana } \\
\text { Kreasi } \\
\text { Nusantara } \\
\end{array}$ & \begin{tabular}{|c|} 
Peraturan \\
Undang - \\
Undang \\
Perpajakan \\
(pasal 11 \\
Undang - \\
Undang \\
PPh No.36 \\
tahun 2008)
\end{tabular} & $\begin{array}{c}\text { Selisis } \\
\text { Laba } \\
\text { Perusahaa } \\
\mathrm{n}\end{array}$ \\
\hline \multirow{2}{*}{$\begin{array}{l}\text { Tahun } \\
2013\end{array}$} & $\begin{array}{l}\text { Biaya } \\
\text { Penyusutan }\end{array}$ & 22.194 .702 & 20.272 .806 & \multirow{2}{*}{1.921 .897} \\
\hline & Laba Perusahaan & 52.144 .289 & 54.066 .185 & \\
\hline \multirow{2}{*}{$\begin{array}{l}\text { Tahun } \\
2014\end{array}$} & \begin{tabular}{|l} 
Biaya \\
Penyusutan
\end{tabular} & $\begin{array}{r}150.413 .92 \\
5 \\
\end{array}$ & 97.499 .917 & \multirow{2}{*}{52.914 .008} \\
\hline & Laba Perusahaan & 32.971 .939 & 85.885 .947 & \\
\hline \multirow{2}{*}{$\begin{array}{l}\text { Tahun } \\
2015\end{array}$} & $\begin{array}{l}\text { Biaya } \\
\text { Penyusutan }\end{array}$ & $\begin{array}{r}182.363 .83 \\
8 \\
\end{array}$ & \begin{tabular}{|r|}
107.851 .01 \\
9
\end{tabular} & \multirow{2}{*}{74.512 .819} \\
\hline & Laba Perusahaan & $\begin{array}{r}100.568 .26 \\
2 \\
\end{array}$ & \begin{tabular}{|r|}
175.081 .08 \\
0 \\
\end{tabular} & \\
\hline \multirow{2}{*}{$\begin{array}{l}\text { Tahun } \\
2016\end{array}$} & $\begin{array}{l}\text { Biaya } \\
\text { Penyusutan }\end{array}$ & $\begin{array}{r}208.358 .96 \\
5 \\
\end{array}$ & $\begin{array}{r}155.787 .48 \\
9 \\
\end{array}$ & \multirow{2}{*}{52.571 .476} \\
\hline & Laba Perusahaan & 95.553 .692 & $\begin{array}{r}148.125 .16 \\
8 \\
\end{array}$ & \\
\hline \multirow{2}{*}{$\begin{array}{l}\text { Tahun } \\
2017\end{array}$} & \begin{tabular}{|l} 
Biaya \\
Penyusutan
\end{tabular} & $\begin{array}{r}217.879 .07 \\
3 \\
\end{array}$ & $\begin{array}{r}158.677 .74 \\
0 \\
\end{array}$ & \multirow{2}{*}{59.201 .333} \\
\hline & Laba Perusahaan & 62.355 .034 & $\begin{array}{r}121.556 .36 \\
7 \\
\end{array}$ & \\
\hline \multirow{2}{*}{$\begin{array}{l}\text { Tahun } \\
2018\end{array}$} & $\begin{array}{l}\text { Biaya } \\
\text { Penyusutan }\end{array}$ & $\begin{array}{r}120.616 .66 \\
3 \\
\end{array}$ & 88.029 .378 & \multirow{2}{*}{32.587 .285} \\
\hline & Laba Perusahaan & 62.607 .563 & 95.194.847 & \\
\hline
\end{tabular}

Pada tahun 2013 berdasarkan perhitungan biaya penyusutan untuk seluruh aset perusahaan berdasarkan kelompok aset tetap, masa manfaat aset tetap, dan tarif penyusutan aset tetap berdasarkan pernyataan standar akuntansi keuangan (PSAK) No.16 pada PT Wahana Kreasi Nusantara sebesar Rp 22.194.702, sedangkan berdasarkan perhitungan biaya penyusutan untuk seluruh aset perusahaan berdasarkan kelompok aset tetap, masa manfaat aset tetap, dan tarif penyusutan aset tetap berdasarkan Peraturan Undang -
Undang Perpajakan (pasal 11 Undang Undang PPh No.36 tahun 2008) sebesar Rp 20.272.806. sehingga selisih laba yang diperoleh perusahaan berdasarkan perhitungan biaya penyusutan menggunakan pernyataan standar akuntansi keuangan (PSAK) No.16 dan Peraturan Undang Undang Perpajakan (pasal 11 Undang Undang PPh No.36 tahun 2008) pada laporan laba rugi PT Wahana Kreasi Nusantara adalah sebesar Rp 1.921.897.

Pada tahun 2014 berdasarkan perhitungan biaya penyusutan untuk seluruh aset perusahaan berdasarkan kelompok aset tetap, masa manfaat aset tetap, dan tarif penyusutan aset tetap berdasarkan pernyataan standar akuntansi keuangan (PSAK) No.16 pada PT Wahana Kreasi Nusantara sebesar Rp 150.413.925, sedangkan berdasarkan perhitungan biaya penyusutan untuk seluruh aset perusahaan berdasarkan kelompok aset tetap, masa manfaat aset tetap, dan tarif penyusutan aset tetap berdasarkan Peraturan Undang Undang Perpajakan (pasal 11 Undang Undang PPh No.36 tahun 2008) sebesar Rp 97.499.917. sehingga selisih laba yang diperoleh perusahaan berdasarkan perhitungan biaya penyusutan menggunakan pernyataan standar akuntansi keuangan (PSAK) No.16 dan Peraturan Undang Undang Perpajakan (pasal 11 Undang Undang PPh No.36 tahun 2008) pada laporan laba rugi PT Wahana Kreasi Nusantara adalah sebesar Rp 52.914.008.

Pada tahun 2015 berdasarkan perhitungan biaya penyusutan untuk seluruh aset perusahaan berdasarkan kelompok aset tetap, masa manfaat aset tetap, dan tarif penyusutan aset tetap berdasarkan pernyataan standar akuntansi keuangan (PSAK) No.16 pada PT Wahana Kreasi Nusantara sebesar Rp 182.363.838, 
sedangkan berdasarkan perhitungan biaya penyusutan untuk seluruh aset perusahaan berdasarkan kelompok aset tetap, masa manfaat aset tetap, dan tarif penyusutan aset tetap berdasarkan Peraturan Undang Undang Perpajakan (pasal 11 Undang Undang PPh No.36 tahun 2008) sebesar Rp 107.851.019. sehingga selisih selisih laba yang diperoleh perusahaan berdasarkan perhitungan biaya penyusutan menggunakan pernyataan standar akuntansi keuangan (PSAK) No.16 dan Peraturan Undang Undang Perpajakan (pasal 11 Undang Undang PPh No.36 tahun 2008) pada laporan laba rugi PT Wahana Kreasi Nusantara adalah sebesar Rp 74.512.819.

Pada tahun 2016 berdasarkan perhitungan biaya penyusutan untuk seluruh aset perusahaan berdasarkan kelompok aset tetap, masa manfaat aset tetap, dan tarif penyusutan aset tetap berdasarkan pernyataan standar akuntansi keuangan (PSAK) No.16 pada PT Wahana Kreasi Nusantara sebesar Rp 208.358.965, sedangkan berdasarkan perhitungan biaya penyusutan untuk seluruh aset perusahaan berdasarkan kelompok aset tetap, masa manfaat aset tetap, dan tarif penyusutan aset tetap berdasarkan Peraturan Undang Undang Perpajakan (pasal 11 Undang Undang PPh No.36 tahun 2008) sebesar Rp 155.787.489. sehingga selisih laba yang diperoleh perusahaan berdasarkan perhitungan biaya penyusutan menggunakan pernyataan standar akuntansi keuangan (PSAK) No.16 dan Peraturan Undang Undang Perpajakan (pasal 11 Undang Undang PPh No.36 tahun 2008) pada laporan laba rugi PT Wahana Kreasi Nusantara adalah sebesar Rp 52.571.476.

Pada tahun 2017 berdasarkan perhitungan biaya penyusutan untuk seluruh aset perusahaan berdasarkan kelompok aset tetap, masa manfaat aset tetap, dan tarif penyusutan aset tetap berdasarkan pernyataan standar akuntansi keuangan (PSAK) No.16 pada PT Wahana Kreasi Nusantara sebesar Rp 217.879.073, sedangkan berdasarkan perhitungan biaya penyusutan untuk seluruh aset perusahaan berdasarkan kelompok aset tetap, masa manfaat aset tetap, dan tarif penyusutan aset tetap berdasarkan Peraturan Undang Undang Perpajakan (pasal 11 Undang Undang PPh No.36 tahun 2008) sebesar Rp 158.677.740. sehingga selisih laba yang diperoleh perusahaan berdasarkan perhitungan biaya penyusutan menggunakan pernyataan standar akuntansi keuangan (PSAK) No.16 dan Peraturan Undang Undang Perpajakan (pasal 11 Undang Undang PPh No.36 tahun 2008) pada laporan laba rugi PT Wahana Kreasi Nusantara adalah sebesar Rp 59.201.333.

Pada tahun 2018 berdasarkan perhitungan biaya penyusutan untuk seluruh aset perusahaan berdasarkan kelompok aset tetap, masa manfaat aset tetap, dan tarif penyusutan aset tetap berdasarkan pernyataan standar akuntansi keuangan (PSAK) No.16 pada PT Wahana Kreasi Nusantara sebesar Rp 120.616.663, sedangkan berdasarkan perhitungan biaya penyusutan untuk seluruh aset perusahaan berdasarkan kelompok aset tetap, masa manfaat aset tetap, dan tarif penyusutan aset tetap berdasarkan Peraturan Undang Undang Perpajakan (pasal 11 Undang Undang PPh No.36 tahun 2008) sebesar Rp 88.029.378. sehingga selisih laba yang diperoleh perusahaan berdasarkan perhitungan biaya penyusutan menggunakan pernyataan standar akuntansi keuangan (PSAK) No.16 dan Peraturan Undang Undang Perpajakan (pasal 11 Undang Undang PPh No.36 tahun 2008) pada 
laporan laba rugi PT Wahana Kreasi Nusantara adalah sebesar Rp 32.587.285.

Tabel-2 merupakan hasil akhir perhitungan biaya penyusutan aset tetap menggunakan kelompok aset tetap, masa manfaat aset tetap, dan tarif penyusutan aset tetap berdasarkan pernyataan standar akuntansi keuangan (PSAK) No.16 dan Peraturan Undang - Undang Perpajakan (pasal 11 Undang - Undang PPh No.36 tahun 2008) pada PT Wahana Kreasi Nusantara, untuk perhitungan biaya penyusutan aset tetap menggunakan metode garis lurus berdasarkan kelompok aset tetap, masa manfaat aset tetap, dan tarif penyusutan aset tetap yang sudah ditetapkan oleh PT Wahana Kreasi Nusantara berdasarkan pernyataan standar akuntansi keuangan (PSAK) No.16 dan perhitungan biaya penyusutan aset tetap menggunakan kelompok aset tetap, masa manfaat aset tetap, dan tarif penyusutan aset tetap berdasarkan Peraturan Undang - Undang Perpajakan (pasal 11 Undang - Undang PPh No.36 tahun 2008).

Dan perbandingan laba yang diperoleh perusahaan berdasarkan perhitungan biaya penyusutan menggunakan pernyataan standar akuntansi keuangan (PSAK) No.16 dan Peraturan Undang Undang Perpajakan (pasal 11 Undang Undang PPh No.36 tahun 2008).

\section{SIMPULAN DAN SARAN}

\section{Simpulan}

Dari hasil penelitian diatas terlihat bahwa

1. Perhitungan biaya penyusutan aset tetap pada PT Wahana Kreasi Nusantara berdasarkan pernyataan standar akuntansi keuangan (PSAK) No.16 menggunakan metode garis lurus.

2. Pengelompokan aset tetap, masa manfaat aset tetap, dan tarif penyusutan aset tetap yang ditentukan oleh perusahaan belum sesuai Peraturan Undang - Undang Perpajakan (pasal 11 Undang - Undang $\mathrm{PPh}$ No.36 tahun 2008). Sehingga dengan perbedaan pengelompokan aset tetap, masa manfaat aset tetap, dan tarif penyusutan aset tetap tersebut berpengaruh pada laporan laba rugi perusahaan.

\section{Saran}

1. Berdasarkan kesimpulan diatas saran yang dapat diberikan kepada PT Wahana Kreasi Nusantara agar lebih memahami lagi tentang penentuan kelompok aset tetap, masa manfaat aset tetap, dan tarif penyusutan aset tetap berdasarkan Peraturan Undang - Undang Perpajakan (pasal 11 Undang - Undang PPh No.36 tahun 2008)

2. Asset tetap merupakan salah satu komponen yang sangat penting dalam laporan keuangan maka, perusahaan harus lebih teliti dan cermat lagi dalam menyajikan asset tetap dilaporan keuangan.

\section{DAFTAR PUSTAKA}

Andika Prianto, 2017, Analisis Perlakuan Akuntansi Peralatan Kantor dan Aktiva Tetap Pada PT Astra Sedaya Finance

Baridwan, Zaki, 2018, Intermediate Accounting, Yogyakarta : BPFE

Haryono, 2005, Dasar-Dasar Akuntansi. Yogyakarta : Akademi Akuntansi YKPN.

Harijanto Sabijono, 2018, Analisis Perhitungan Penyusutan Aktiva Tetap 
Menurut Standar Akuntansi Keuangan dan Peraturan Perpajakan pada CV Samia Sejahtera.

Hery, 2014,Akuntansi Untuk Pemula Update, Revisi, Cetakan Pertama, Jakarta: Gava Media

Ikatan Akuntan Indonesia (IAI), 2014, Standar Akuntansi Keuangan September 2014, PSAK 16

IkatanAkuntan Indonesia (IAI), 2014, Standar Akuntansi Keuangan

September 2014, PSAK 17

Kartikahadi, Hans, et al, 2016, Akuntansi Keuangan Berdasarkan SAK berbasis IFRS. Jakarta: Ikatan Akuntan Indonesia James, dkk, 2013, Pengantar Akuntansi Adaptasi Indonesia, Jakarta : Salemba Empat

Markus Muda, 2017, Analisis Perhitungan Metode Penyusutan Aktiva Tetap Menurut PSAK No.16 dan Undang Undang Perpajakan Serta Pengaruhnya Terhadap Laporan Keuangan PT Kalanafat Putra

Natalia, 2018, Analisis Perhitungan Penyusutan Aktiva Tetap Menurut Standar Akuntansi Keuangan dan Peraturan Perpajakan Pada CV Samia Sejahtera.

Ng, Eng Juan, Wahyuni, Ersa Tri, 2013, Panduan Praktis Standar Akuntansi Keuangan, Jakarta Selatan : Salemba Empat

Nelson Lam, Peter Lau, 2014, Akuntansi Keuangan Intermediate Financial Reporting, Jakarta : Salemba Empat

Nordiawan,dedi, Sondi Putra, \& I Rahmawati M. 2007, Akuntansi Pemerintahan, Jakarta : Salemba Empat

Peraturan Pemerintah Republik Indonesia Nomor 71 Tahun 2010 Tentang Standar Akuntansi Pemerintah
Peraturan Menteri Dalam Negeri Nomor 64 Tahun 2013 tentang Penerapan Standar Akuntansi Pemerintahan Berbasis Akrual pada Pemerintah Daerah.

Peraturan Menteri Keuangan No.96/KMK.03/2009 Tanggal 15 Mei 2009 mengatur tentang jenis - jenis harta yang termasuk dalam kelompok harta berwujud bukan bangunan untuk keperluan penyusutan, berlaku sejak 1 Januari 2009

Pontoh, Winston, 2013, Akuntansi Konsep dan Aplikasi, Jakarta Barat : Penerbit Moeka

Rudianto, 2012, Pengantar akuntansi“ konsep \& tehnik Penyusunan Laporan Keuangan, Jakarta : Erlangga

Samryn, 2015, Pengantar Akuntansi “ Metode Akuntansi untuk Elemen Laporan Keuangan”, Jakarta : PT. Raja grafindo Persada

Suandy, Erly, 2011, Perencanaan Pajak, Jakarta : Salemba Empat

Tjahjoni, Achmad, \& Muhammad Fakhri Husein, 2005, Perpajakan, Yogyakarta: Unit Penerbit dan percetakan Akademi Manajemen Perusahaan YKPN

Undang - Undang Perpajakan menurut ketentuan perpajakan pasal 11 Undang Undang PPh No.36 tahun 2008

Undang-Undang Nomor 17 Tahun 2000, 2001, Pajak Penghasilan, Jakarta: Salemba Empat.

Yuvita M, Analysis calculation of depreciation fixed assets according to financial accounting standards and tax laws as well ad impact on txable income PT Massindo Sinar Pratama Manado.

Waluyo, 2016, Akuntansi Perpajakan, Jakarta : Salemba Empat 
ISSN : 2406-7415

e-ISSN : 2655-9919

JURNAL AKUNTANSI DAN BISNIS KRISNADWIPAYANA

Vol. 7 No. 1 (Januari - April) 2020

DOI: http://dx.doi.org/10.35137/jabk.v7i1.376 